UDC 94(47).084.6

Submitted: 28.01.2018

LBC 63.3(2)61

Accepted: 20.07.2018

\title{
"THIS SCANDAL COULD LAST FOR MONTHS". STAGES AND OUTCOME OF THE CONFLICT OF G.P. FEDOTOV WITH THE BOARD OF ST. SERGIUS ORTHODOX INSTITUTE IN PARIS IN 1939
}

\author{
Anton A. Voytenko \\ Centre for Egyptological Studies, Russian Academy of Sciences, Moscow, Russian Federation
}

\begin{abstract}
Introduction. The paper investigates the stages and outcome of the conflict of Georgy Fedotov with the Board of the Orthodox Institute in Paris (first half of 1939). Methods and materials. The paper focuses on the published materials of G. Fedotov's correspondence during the conflict, as well as on his article To Defense of Ethics, the article by Nikolay Berdyaev, Yu. Semenov's brief article and memoirs. Analysis. It can be established that the conflict had two stages of its development. Tactics by Fedotov and his supporters in the first stage was to organize a broad campaign in his defense in the emigre press. However, due to the position of P. Milyukov and the newspaper Poslednie Novosti, the tactics failed, and the position of Fedotov's opponents on the Board were strengthened. In the second phase of the conflict, Fedotov and a group of his supporters changed tactics. Now the idea of organizing a campaign in the foreign press and the promulgation of information on the conflict to the foreign sponsors of the Institute had put in the forefront. A publication of N. Berdyaev's article in Fedotov's protection in the journal Put had played a principal role in the second phase of the conflict. The Board members feared a further publicity of the conflict and chose to cease it: they did not remove Fedotov's reprint, but he was allowed to teach at the Institute, and the issue of his expulsion had no longer been risen. Fedotov subsequently published an article To Defense of Ethic, where he attempted to understand the basic reasons for the behavior of his opponents and his ideological differences with them. Fedotov was inclined to see the reasons for their actions in the ideology of "Church Revival" (i.e. orthodox modernism), the main feature of which was the replacement of ethics with aesthetics, which is expressed in understanding of monastic asceticism as moral theology. From his point of view, the application of the principles of asceticism to the behavior of a Christian in the world crashes inevitably and leads either to inactivity or to conformism. The Christians, refusing to elaborate independent moral teaching for life in the world, are not able to meet the actual challenges. Results. Based on the studied materials, it can be concluded that Fedotov's conflict was a conflict with the whole Board of the Institute, and not with its individual members. The underlying causes of the conflict lay in the ideological differences between Fedotov and the members of the Board. The author of the article argues with the recently expressed point of view that the conflict did not have some fundamental reasons, only the position of Fedotov's wife played the decisive role in its later interpretations (published materials of Fedotov's correspondence do not confirm it). The author also argues with the established point of view that the beginning of the Second World War played the main role in resolving the conflict. In his oppinion, the beginning of the war did not affect the conflict, because all the important decisions had been made a few months earlier.
\end{abstract}

Key words: history of Russian emigration, Georgy Petrovich Fedotov, St. Sergius Orthodox Institute in Paris, Nikolay Alexandrovich Berdyaev, philosophy of ethics, Bakhmetyev's archive (Columbia University, USA).

Citation. Voytenko A.A. "This Scandal Could Last for Months". Stages and Outcome of the Conflict of G.P. Fedotov with the Board of St. Sergius Orthodox Institute in Paris in 1939. Vestnik Volgogradskogo gosudarstvennogo universiteta. Seriya 4, Istoriya. Regionovedenie. Mezhdunarodnye otnosheniya [Science journal i of Volgograd State University. History. Area Studies. International Relations], 2018, vol. 23, no. 6, pp. 94-106. (in Russian). DOI: https://doi.org/10.15688/jvolsu4.2018.6.6 


\title{
«МОЖЕТ БЫТЬ, ЭТОТ СКАНДАЛ НА ЦЕЛЫЕ МЕСЯЦЫ». ЭТАПЫ И ИТОГИ КОНФЛИКТА Г.П. ФЕДОТОВА С ПРАВЛЕНИЕМ БОГОСЛОВСКОГО ИНСТИТУТА В ПАРИЖЕ В 1939 ГОДУ
}

\author{
Антон Анатольевич Войтенко \\ Центр египтологических исследований РАН, г. Москва, Российская Федерация
}

\begin{abstract}
Аннотация. Статья посвящена исследованию этапов и результатов конфликта Г.П. Федотова с Правлением Богословского института в Париже (первая половина 1939 г.). На основании опубликованных материалов можно установить, что конфликт имел два этапа своего развития. На первом этапе тактика Федотова и его сторонников заключалась в том, чтобы организовать широкую кампанию в его защиту в эмигрантской прессе. Однако из-за отказа П.Н. Милюкова и газеты «Последние новости» публиковать материалы в защиту Федотова эта тактика потерпела поражение и укрепила позиции его противников в Правлении. На втором этапе развития конфликта Федотов и группа его сторонников поменяли тактику: теперь на первое место выдвинулась идея организации кампании в зарубежной прессе и обнародования конфликта перед иностранными спонсорами институга. Ключевую роль на втором этапе конфликта сыграла публикация статьи Н.А. Бердяева в защиту Федотова в эмигрантском журнале «Путь». Испугавшись дальнейшей огласки, Правление предпочло замять конфликт: порицание с Федотова не сняли, но ему разрешили преподавать в институге, и вопрос о его исключении более не поднимался. Впоследствии Федотов опубликовал статью «В защиту этики», где предпринял попытку осмыслить причины поведения своих противников и идейные расхождения с ними. Причины их действий Федотов склонен видеть в идеологии «церковного возрождения» (то есть православного модернизма), основной особенностью которого является подмена этики эстетикой, что выражается во взгляде на аскетику как на нравственное богословие. Применение принципов аскетики для поведения христианина в миру неизбежно терпит крах и приводит либо к пассивности, либо к конформизму. Отказавшись от выработки самостоятельного нравственного богословия для жизни в миру, христиане оказываются неспособными отвечать на вызовы времени. Автор публикации спорит с высказанным недавно мнением о том, что конфликт Федотова с Правлением не носил принципиального характера и решающую роль в нем сыграла позиция жены Федотова (опубликованные архивные материалы этого не подтверждают). Автор также спорит с устоявшейся точкой зрения, что главную роль в разрешении конфликта сыграло начало Второй мировой войны. По его мнению, начало войны никак не повлияло на разрешение конфликта, поскольку все принципиальные решения были приняты за несколько месяцев до этого.

Ключевые слова: история русской эмиграции, Георгий Петрович Федотов, Богословский институт в Париже, Николай Александрович Бердяев, философия этики, Бахметьевский архив (Колумбийский университет, США).
\end{abstract}

Цитирование. Войтенко А. А. «Может быть, этот скандал на целые месяцы». Этапы и итоги конфликта Г.П. Федотова с Правлением Богословского института в Париже в 1939 году // Вестник Волгоградского государственного университета. Серия 4, История. Регионоведение. Международные отношения. - 2018. - Т. 23, № 6. - C. 94-106. - DOI: https://doi.org/10.15688/jvolsu4.2018.6.6

Введение. Важным этапом в биографии известного деятеля русского зарубежья Георгия Петровича Федотова (1886-1951) был его конфликт с Правлением Богословского института в Париже, начавшийся в феврале 1939 г. и продлившийся почти полгода (в то время Федотов находился в отпуске в Англии, где начал работать над своей последней книгой «Тhе Russian Religious Mind»). Анализу «сторон» этого конфликта и их позиций мы посвятили от- дельную статью [5]. Формальным поводом к нему послужили некоторые выражения в одной из статей Федотова, написанных для журнала А.Ф. Керенского «Новая Россия». Статья вызвала нападки в правоэмигрантской газете «Возрождение» и обвинения в адрес Богословского института. Однако подлинные причины конфликта лежат глубже. Мы уже отмечали, что в институте Федотов так и не сблизился почти ни с кем из его преподавате- 
лей [5, с. 61]. Круг его идейных единомышленников находился за стенами института в штаб-квартире «Православного дела» на улице Лурмель, в кругу Н.А. Бердяева и его «интеллектуального салона», собиравшегося по воскресеньям на квартире философа в Кламаpe. Помимо личной неприязни части профессоров института к Федотову и «архетипичной» причины подобных конфликтов, обычно связанной с противоречием между свободой высказывания члена интеллектуальной корпрорации и принципами корпоративной этики (подлинными или мнимыми), глубинными причинами конфликта могли быть разные представления об идеале христианской жизни (деятельной или созерцательной), восходящие еще к позднеантичным временам. Именно эти глубинные причины были вскрыты Федотовым в его статье об этике [10].

Методы. На основании опубликованных на сегодняшний день документов можно выявить не только «стороны» конфликта, но и основные фазы его протекания, определить (с достаточно большой долей достоверности) цели, стратегию и тактику конфликтующих сторон. Правда, стоит сразу уточнить, что если план действий Федотова и его соратников восстанавливается на основе переписки довольно хорошо, то тактику «противоположной стороны» реконструировать значительно сложнее.

Материалы. Основными источниками анализа будут опубликованная переписка Федотова с его соратниками и оппонентами во время конфликта [3; 7], заметка Ю.Ф. Семенова в правоэмигрантской газете «Возрождение» [9], статьи Н.А. Бердяева «Существует ли в православии свобода мысли и совести?» [2] и Г.П. Федотова «В защиту этики» [10], воспоминания В.С. Яновского [12] и биографический очерк вдовы Г.П. Федотова Е.Н. Федотовой [11].

Анализ. Изучение имеющихся в нашем распоряжении данных показывает, что конфликт имел два этапа своего развития. Первый этап начался со времени постановления Правления от 8 февраля, а также писем о. Сергия и митрополита Евлогия к Федотову (соответственно от 9 и 10 февраля). Закончился этот этап письмом митрополита Евлогия к Федотову от 20 апреля, где он сообщает о подтвер- ждении порицания, вынесенного ему на заседании Правления 30 марта. После этого начался второй этап, который был связан с изменением тактики «стороной Федотова». В целом этот этап завершился в начале лета: в своем письме к жене в июне Федотов приводит ее слова о том, что его дело в институте «считается ликвидированным» [3, с. 368]. Вероятно, некоторые «арьергардные бои» продолжились и после: письмо В.В. Зеньковского к Федотову от 23 июня указывает на то, что группа его противников все еще пытается организовать кампанию против Н.А. Бердяева в эмигрантской прессе, но, как мы знаем, эта попытка закончилась провалом.

Сразу после получения Федотовым письма от митрополита с ультиматумом он склоняется к мысли принять его условия и прекратить заниматься политической публицистикой. Мотив своего решения он объясняет работой над книгой и отсутствием поддержки своих соратников (м. Марии (Скобцовой) и И.И. Фондаминского) в нападках на него после появлении статьи «Пассионария» тремя годами ранее. «В прошлом моем (“испанском”) конфликте я видел со стороны м. Марии равнодушие, а со стороны Ильи Ис. желание капитулировать», - пишет он жене [3, с. 283]. Но после получения письма от м. Марии (от 12 февраля) Федотов резко меняет свою позицию. Чувствуя поддержку друзей из «Православного дела», он готов идти до конца, поскольку теперь это дело принципа: «Теперь я вижу, что я не один, что мое дело - общее. Это и радует, и меняет положение. Теперь я не имею права подчиняться, раз дело пошло о праве православного писателя выражать свои мнения» [3, с. 285]. С этого времени речь идет лишь о совместной выработке тактики борьбы «стороной Федотова».

Помимо переговоров с митрополитом Евлогием (эту функцию берет на себя м. Мария), основной идеей становится организация отклика на конфликт в эмигрантской прессе. И принципиальным положением этой идеи является организация статей во всех ее сегментах, кроме правомонархического. Идея проста и понятна: показать, что решение Правления не нашло понимания ни в одном лагере русской эмиграции, кроме крайне правых. Основным вопросом становится публи- 
кация статьи в газете «Последние новости», главным редактором которой был П.Н. Милюков. Следует напомнить, что после того как главным редактором «Возрождения» стал Ю.Ф. Семенов и газета стала придерживаться крайне правых позиций, часть ее сотрудников перешла работать в «Последние новости». Таким образом, публикация статьи, поднимающей вопрос о недопустимости подавления свободы слова, в популярном в эмигрантской среде центристском издании давала бы «стороне Федотова» очень большие козыри. Статью должен был написать помощник главного редактора И.П. Демидов. Переговоры с ним вела м. Мария, было получено его принципиальное согласие. Однако изза позиции П.Н. Милюкова или его жены публикация не состоялась. Для «стороны Федотова» это был серьезный удар, и, судя по переписке, она это хорошо осознавала.

Однако уже на первом этапе конфликта «сторона Федотова» обсуждает и другую тактику. И здесь следует вспомнить хорошо известный факт: Богословский институт финансировался англиканскими фондами, организацией ИМКА и другими экуменическими организациями. Обе стороны конфликта (и «сторона Федотова», и Правление) отлично понимали, что огласка конфликта в западной прессе и знакомство с ситуацией их спонсоров могут иметь своим последствием значительные проблемы с финансированием. Именно с этих позиций следует рассматривать ряд высказываний и действий участников конфликта. На это ясно и недвусмысленно указывает Федотов в своем официальном ответе Правлению, когда пишет, что «круги, которые стоят за "Возрождением", ни морально, ни материально (курсив наш. - A. В.) не поддерживают Института», и далее отмечает, что «круги, действительно ценящие Институт и поддерживающие его, могут поколебаться в своем сочувствии ему» [3, с. 277-278]. На это же намекает Ф.Т. Пьянов в письме к Федотову после знакомства с текстом его официального ответа: «Я совершенно уверен в том, что по соображениям материального характера и все недруги будут стоять сейчас за отмену резолюции» [3, с. 297]. Он также просит разрешения Федотова ознакомить с этим делом Перси Видрингтона, англиканского священни- ка, социалиста и секретаря фонда, который поддерживал «Православное дело». Наконец, в переписке всплывает такая фигура, как Пол Андерсон, один из активных деятелей ИМКА, который, судя по всему, был посредником между институтом и некоторыми организациями, его финансирующими. В своем послании к жене от 18 февраля Федотов замечает: «Вчера получил письмо от Андерсона, который пишет, что был у митрополита и изложил ему свой взгляд: с обеих сторон здесь затронуты “важные факторы”, всякое радикальное решение произвело бы неблагопрятное впечатление за границей, и время и переписка могут смягчить остроту конфликта. От меня он ничего не требовал и кончил напоминанием о “соборности”. В общем, я имею основание быть довольным его вмешательством» [3, c. 290]. Из письма Федотова к жене от 1820 февраля мы узнаем о ее переговорах с Андерсоном, а Федотов указывает ей верную линию поведения: «С Андерсоном, я думаю, ты держишь правильную линию, если только не обидела его. Трудность в том, чтобы не иметь вид угрожающей (и шантажирующей) стороны» [3, с. 330]. В одном из писем он сообщает жене, что иностранцы и для него, и для института важнее русской эмиграции [3, c. 311], имея в виду, вероятно, те круги западных экуменистов, которые сочувствовали институту и материально поддерживали его. Тем не менее Федотов на первом этапе конфликта не хотел использовать этот козырь и всячески останавливал попытки (например, о. Льва Жилле) сообщить о конфликте в иностранной прессе. Мотив Федотова понятен: он считал, что знакомство западных кругов с позицией института будет для последнего позором, чего он - при всех сложных отношениях с Правлением - не хотел. Поэтому он предпочел кампанию в эмигрантской прессе и намеки на возможные осложнения с западными спонсорами института. Федотов достаточно ясно указывал, чего он добивался: полная отмена постановления о вынесенном ему порицании и сообщение об этом публично, то есть появление информации об этом в прессе.

Теперь посмотрим, как протекал конфликт в феврале - конце апреля 1939 года. После получения письма от митрополита с извинениями и известия о возможной статье Де- 


\section{ОТЕЧЕСТВЕННАЯ ИСТОРИЯ}

мидова у Федотова появляется надежда, что конфликт будет решен в его пользу и порицание будет снято. Однако из письма к жене от 25 февраля он узнает, что кампания в прессе провалена: статья в «Последних новостях» не выйдет, а публикация А.Ф. Керенского в «Новой России», по его мнению, лишь подчеркивала его изоляцию [3, с. 307-310]. Нам представляется, что в данном случае Федотов был совершенно прав. Достаточно прочесть язвительную заметку Семенова на отклик Керенского, где он, в частности, пишет: «Защитить по существу ересь Федотова о христианскижертвенном принесении России в жертву интернационалу г. Керенский и не пробует: он признает, что “левые высказывания Федотова подчас звучат очень острыми парадоксами". Но его огорчает, что владыка-митрополит Евлогий признал законность протеста русских людей против острых федотовских парадоксов. <...> Но каков Керенский - в роли “арбитра" между владыкой-митрополитом и его паствой» [9]. Видимо, к этому времени о провале кампании знают уже и противники Федотова в институте. Судя по его письму, жена советует ему смягчить свои требования и, вероятно, переделать официальный ответ Правлению. Федотов, по сути, упрекает ее в малодушии и пишет, что будет ждать ответного хода своих противников. Он пишет о необходимости продолжить кампанию в прессе, хотя здесь «мы уже наполовину разбиты» [3, с. 309].

Интересный момент: в одном из писем Федотов упоминает о заседании Правления, которое должно было пройти 28 февраля 1939 г. (см.: [3, с. 315]). По его версии, это заседание, если и было, не пришло ни к какому решению относительно его дела. Из последующей переписки становится ясно, что его ответ Правлению с предложением отменить вынесенное ему порицание на этом заседании также официально не рассматривался. Однако неделю спустя о. Георгий (Флоровский) и В.В. Зеньковский посылают ему совместное письмо. Из него следует, что, скорее всего, группа его противников уже знала о провале кампании в прессе, ответ Федотова официально рассмотрен не был и от него по-прежнему требовали ограничений в публицистической деятельности. По сути, это была разведка с целью узнать, не изменилась ли позиция Фе- дотова. В письме к жене он дает исчерпывающую характеристику тактике своих противников: «Не только не видно ни малейших следов "раскаяния", но они настаивают на своем праве контролировать политические выступления профессоров, поскольку от них может произойти вред для института. $<\ldots>$ В своем частном письме, которое ничуть не “ласковее" общего (в сущности, оба проникнуты горечью обиды), он [Зеньковский] ждет от меня ответа: хочу ли я остаться в Институте, и если да, то на какие уступки я могу пойти. Свою резолюцию они не сняли, и Зеньковский говорит только о возможности ее изменения в случае моих уступок. Мой ответ они отказываются рассматривать официально. Не знаю, о чем это говорит: о желании от меня отделаться, о своей безнаказ(ан)ности (ввиду позиции Милюкова) или просто о раздражении, вызванном моим ответом» ${ }^{1}[7$, с. 327$]$.

Известно, что на заседании Правления 30 марта 1939 г. ответ Федотова Правлению был официально рассмотрен и предыдущее решение было официально подтверждено. Интересно другое: митрополит Евлогий отправляет Федотову письмо с извещением об этом только 20 апреля, то есть больше, чем через две недели после решения Правления. Мало того, Федотову даже в апреле посылаются знаки о том, что постановление Правления могут отменить и заменить его неофициальным письмом с просьбой воздержаться от политической публицистики [3, с. 335], что в Париже все настроены примирительно и никто не хочет его ухода [3, с. 347]. Можно предполагать разные варианты, но причины двухнедельной отсрочки объявления Федотову резолюции Правления остаются неясными.

После этого наступает второй этап конфликта, где «сторона Федотова» меняет тактику. Поначалу Федотов хочет выждать: он пишет, что «шум», то есть, вероятнее всего, кампанию в заграничной прессе, следует поднимать только после его увольнения из института [3, с. 347]. Однако «Православное дело» и Н.А. Бердяев предлагают другой сценарий направить в Правление еще одно письмо с подтверждением своего права на свободные политические высказывания в прессе, но с обещанием воздерживаться в них от неосторожных выражений, которые могли бы нанес- 
ти вред институту. Как видно из текстологического анализа, Федотов в своем официальном ответе Правлению от 20 мая 1939 г. практически целиком воспроизвел тот проект ответа, который был выработан на заседании «Православного дела» и отправлен ему [3, c. 358, 361-362]. Из письма м. Марии от 17 мая мы узнаем о ее разговоре с митрополитом Евлогием, где как раз и упоминается о «группе», добивающейся ухода Федотова из института (см.: [5, с. 61-62]), а также о том, что ответ Федотова, содержащий в себе два вышеперечисленных пункта (право на публицистику и обязанность быть осторожным в высказываниях), необходим митрополиту для того, чтобы нейтрализовать дальнейшие действия этой «группы».

Проект Бердяева был более радикальным и предусматривал, помимо прочего, перевод его находящейся в печати статьи на английский и организацию кампании в западной прессе («устроить международный бум») [3, с. 356]. Речь идет о статье «Существует ли в православии свобода мысли и совести?», опубликованной в № 59 журнала «Путь». Когда была задумана и написана статья точно неизвестно, но, вероятнее всего, она должна была быть частью кампании в эмигрантской прессе, о которой мы уже писали. У Федотова в письме от 23 февраля 1939 г. мы находим фразу, что газетная кампания от него не зависит, «раз Демидов и Бердяев взялись за это дело» [3, с. 306]. Зато можно примерно указать срок выхода этой статьи из печати: между 17 и 27 мая 1939 года. В письме м. Марии от 17 мая сообщается, что статья выйдет «в майской книжке "Пути”»), а в письме к жене от 27 мая Федотов уже пишет, что получил экземпляр этого журнала со статьей.

Публикация статьи Бердяева становится ключевым событием второго этапа конфликта и, судя по данным переписки, решительно меняет расстановку сил. По письмам Зеньковского Федотову и по реакции Федотова на них становится ясно, что статья произвела в рядах Правления переполох и явно его напугала. Для того чтобы понять, что так испугало Правление, стоит внимательно проанализировать некоторые пассажи этой статьи. Бердяев пишет: «Справедливы ли со стороны православных постоянные обвинения католиков, что у них нет свободы, обвинения, основанные на предположении, что у самих православных эта свобода есть. И ставится еще другой вопрос: связано ли Православие с определенной политической системой, например, с монархизмом, национализмом, сословным строем, по моде сегодняшнего дня, с фашизмом, или оно допускает различные точки зрения? Может ли православный, оставаясь профессором православной духовной школы, быть демократом, социалистом, быть защитником свободы, социальной справедливости, достоинства человека? Вопрос этот очень остро ставится тягостным случаем с Г.П. Федотовым. По предложению митрополита, профессора Богословского института предъявили Г.П. Федотову ультиматум: или уйти из профессоров Богословского института, или перестать писать статьи на политические темы в “Новой России” и других органах “левого” уклона. < ... > Речь шла не о статьях на богословские темы, а о статьях политических. Обвинение было в том, что статьи “левые" и что автор не может быть причислен к "национально мыслящим". Признается недопустимым для профессора Богословского института заниматься политикой. Но это неправда. Профессорам Богословского института разрешается сколько угодно заниматься политикой, но исключительно “правой” политикой. Никто не предложил бы профессору Богословского института выйти из состава профессуры, если бы он написал статью в защиту монархической реставрации и крайней национальной политики. Один из профессоров даже возглавлял правую националистическую организацию. $<\ldots>$ Совершенно ясно, что осуждение Г.П. Федотова профессурой Богословского института было именно политическим актом, актом глубоко компрометирующим это учреждение, бросая на него тень реакционности» [2, c. 46-47]. Далее Бердяев пишет: «Приведу пример. Жак Маритен, самый выдающийся католический мыслитель Франции, профессор Institut Catholique, защищает христианскую демократию, христианский гуманизм, достоинство и свободу человеческой личности, обличает антихристианскую ложь антисемитизма, особенно горячо обличает генерала Франко, прикрывающегося католичеством, он говорит и пишет почти то же, что Г.П. Федотов, 
и его никто не трогает, ему не предлагают покинуть высшую католическую школу Франции» [2, с. 51]. Н.А. Бердяев на тот момент был директором издательства «ИМКАпресс», дружил или был знаком со многими интеллектуалами во Франции и Германии, его труды переводились на европейские языки и к его мнению (он, по сути, в это время был самым читаемым на Западе русским философом), безусловно, прислушивались те экуменические круги, которые спонсировали работу Богословского института. Правление института не могло не понимать, что публичное оглашение мнения Бердяева в западной прессе либо создало бы институту большие проблемы с финансированием (которое и так поступало нерегулярно), либо прекратило бы его вовсе. Косвенно это подтверждает конфликт Н.А. Бердяева с П. Андерсоном после публикации статьи [4, с. 473]. Последний указывает Бердяеву, что институту нанесен тяжелый удар. Андерсон, как это видно из переписки Федотова с женой, придерживался линии компромисса и, видимо, надеялся, что широкой огласки не будет. Болея за институт, он, вероятно, хорошо понимал, чего будет стоить информация об этом деле в западной прессе.

В ответ Правление (а скорее всего, «группа») попыталось организовать в прессе кампанию против Бердяева, обвинить его в искажении картины и тем самым реабилитировать себя. Федотов пишет, что кампанию против Бердяева затеял Зеньковский [3, c. 359], но, вероятнее всего, он был просто одним из ее участников. Из переписки ситуация вырисовывается следующим образом. После публикации статьи Бердяева было составлено послание за подписью Правления для рассылки в эмигрантские периодические издания, где указывалось, что Бердяев исказил факты, и выражалось намерение напечатать документы, относящиеся к конфликту [3, с. 374375]. Письмо было разослано в «Новую Россию», «Путь», «Последние новости» и, вероятно, в какие-то иные эмигрантские издания. В ответ А.Ф. Керенский в «Новой России» перепечатал статью Бердяева со своим предисловием, а «Последние новости», как и в случае с предложением «стороны Федотова» (статья Демидова), отказались печатать чтолибо по этому делу. По сути, после этого кам- пания против Бердяева провалилась. О публикации Правлением каких-либо документов, связанных с этим делом, нам неизвестно. Похоже, история закончилась лишь демаршем отдельных его членов, которые отказались сотрудничать с Бердяевым в его Религиознофилософской академии и журнале «Путь».

Федотов очень позитивно воспринял публикацию статьи Бердяева. Он писал жене: «Испытываю нравственное удовлетворение, что кто-то сказал правду и - это уже личное кто-то заступился за мою честь» [3, с. 363]. Федотов отлично осознавал слабость позиций своих противников и особое положение Бердяева, о котором мы сказали выше. В письме к жене Федотов замечает: «Он [Зеньковский] должен понимать, что война с Бердяевым может стоить жизни институту» [3, с. 369]. Одно из писем Федотова Бердяеву посвящено предполагаемому ответу Бердяева на кампанию Правления. Федотов пишет, что будет вынужден воздержаться от публичной поддержки его статьи, но выражает солидарность с ним и указывает на слабость аргументов противоположной стороны [3, с. 372-374].

Очень интересно письмо Зеньковского к Федотову от 23 июня. Как мы уже указывали, Федотов полагал, что по позиции и действиям Зеньковского можно судить об изменениях настроений в Правлении [5, с. 62]. К тому же Федотов намекал на одну интересную особенность поведения своих противников, когда (после получения известий о содержании заседания Правления, состоявшегося 30 марта) писал, что «они опять от писем перешли к резолюциям» [3, с. 350]. Таким образом, письма противоположной стороны к Федотову посылались тогда, когда она чувствовала неуверенность или даже испуг. Когда «группа» была уверена в успехе своих действий, она этого не делала. Если посмотреть на письмо Зеньковского с этой точки зрения, то оно действительно демонстрирует испуг Правления, вызванный публикацией статьи Бердяева, широкой оглаской конфликта в эмигрантских церковных кругах («мы получили ряд запросов (большинство из Эстонии)» [3, с. 375]) и страхом того, что увольнение Федотова из института вызовет скандал. В этой ситуации Правление выбрало самое верное для себя решение: оно, чтобы сохранить лицо, не сняло с 
Федотова порицания, но оставило его в институте и замяло («ликвидировало») это дело. Если бы вопрос о порицании приобрел такой же резонанс, как предполагаемая отставка Федотова, можно не сомневаться в том, что и оно было бы снято.

Безусловно, о страхе профессоров потерять «экзистенц-минимум» в случае, если экуменические организации, поддерживающие институт, узнают всю подноготную кампании против Федотова, Зеньковский не сообщает. Было бы странно надеяться на это в письме, которое не носит доверительного характера. Однако именно на это, скорее всего, намекает сам Федотов в письме к жене, где он анализирует причины поведения Зеньковского: «Или он [Зеньковский] лучше меня знает настроение заграничных кругов?» [3, с. 369]. Намек именно на такой возможный поворот дела содержится в мемуарах В.С. Яновского. Он приводит только один, зато довольно ясный аргумент, чем именно привели в чувство ту «светлую личность» (см.: [5, с. 62]), которая требовала отставки Федотова как «тайного масона и марксиста»: «Богословский институт поддерживался англиканскими филантропами и одернуть эту “светлую личность” оказалось делом не трудным» [12, с. 53].

Сам Федотов не скрывает в переписке ни своего отношения к Правлению, ни своих причин возвращения к преподаванию в институте. Он, безусловно, считает, что Правление совершило бесчестный поступок, и тяготится своим пребыванием в институте, но остается в нем из-за студентов [3, с. $353,354,365]$. Своим выходом из состава Правления он ясно показывает, что желает минимизировать свои контакты с профессурой института, о чем достаточно откровенно пишет в письме к жене: «Останусь ли я в Институте $>$ <..> Если останусь, какая трудная жизнь... ...сидеть в Институте с врагами. Ты права: надо уйти из Правления, на это у меня не хватит ни выдержки, ни сил. Остается митрополит и личные отношения. Ах, теперь бы начать новую жизнь - совершенно новую. Силы еще есть последние - писать то, что думаешь, все, что думаешь, и только то, что думаешь. Мечты!» [3, c. 367].

Такая же ситуация сложилась у Федотова ранее с коллегами по Саратовскому уни- верситету, о чем вспоминала его жена [11, c. XV-XVI]. Суть конфликта была та же: Федотов не мог поступиться свободой своей позиции (неприятие большевизма) и определеным выражением этой позиции (отсутствием на первомайских демонстрациях и на мероприятии, где нужно было стоять под красным флагом и петь «Интернационал»), что послужило причиной для обвинений его в нарушении корпоративной этики. Результатом конфликта, как известно, стал разрыв Федотова с Саратовским университетом и его переезд в Петроград.

Из переписки ясно, что Федотов планировал вернуться в Париж 28 июля [3, с. 360], однако Д. Бон указывает (не называя источников), что Федотов вернулся во Францию в середине августа [7, с. 151], жена Федотова пишет, что он вернулся за три недели до начала войны [11, с. XXVI]. Д. Бон также (без ссылок на источники) сообщает, что Федотов еще некоторое время преподавал в институте [7, c. 151]. Что произошло потом, хорошо известно: воспользовавшись предложением Американского еврейского рабочего комитета о предоставлении виз «вне квот и консульских формальностей» $[11$, с. XXVIII] и получив благословение у митрополита Евлогия, Федотов отбыл в США. Начался новый период его жизни. Причины, по которым митрополит благословил Федотова на отъезд в Америку, понять несложно. После оккупации Парижа те из правомонархических кругов эмиграции, кто оказался в нацистском обозе, не преминули бы свести с Федотовым счеты, поскольку среди всех участников «Православного дела» он, благодаря своей политической публицистике, был наиболее известной и уязвимой фигурой. Судьба двух соратников Федотова по этой организации, м. Марии (Скобцовой) и И.И. Фондаминского, красноречиво это подтверждает: они оба погибли в нацистских концлагерях.

Помимо того, что конфликт с Правлением Богословского института оставил серьезный след в душе Федотова, он побудил его к рефлексии, к попыткам разобраться в тех причинах, которые послужили основой для такого поведения профессоров института. Результатом этой рефлексии стала статья «В защиту этики», впервые опубликованная в № 60 
журнала «Путь» [10]. Федотов не скрывал, что пишет эту статью как развернутый ответ Правлению института. В переписке он упоминает, что эта статья будет ответом о. Сергию (Булгакову) и его направлению [3, с. 354]. Однако наиболее ясно замысел своей статьи Федотов объясняет в письме к жене от 1920 августа 1949 г.: «Мое презрение к тому роду церковности (применительно к подлости), которое определяло их поведение по отношению ко мне... <..> Мстить за свои обиды мне кажется низким. У меня другие формы реакции: я мщу той подлой экклезиологии, которая приводит к таким поступкам. Я считаю, что моя статья об этом в "Пути" (1939) и моя печатающаяся книга достаточно мстят за меня» (цит. по: [4, с. 475]).

Статья Федотова, особенно в последней части, представляет собой критику православного модернизма, но не с консервативно-охранительных позиций карловацкой публицистики, а с позиций христианской этики (так, как Федотов ее понимал). Истоки православного модернизма (Федотов называет его «церковным возрождением») он возводит к тем общим для истории русской культуры процессам, которые начались после революции 1905 года. До этого, с 30-х гг. XIX в., господствующей идеей русской интеллигенции было «нравственное подвижничество». В жертву морали она приносила все: «религию, культуру, государство, искусство и, наконец, и самую мораль» $[10$, с. 5$]$. На этой максиме выросло три поколения русских интеллигентов. Вся великая русская литература XIX в. зиждилась на этической, а не на эстетической установке («это была, в своем нраственном горении, христианская литература, - быть может, единственная христианская литература нового времени») [10, с. 5]. Но с разгромом первой русской революции все изменилось. С одной стороны, Федотов оценивает пореволюционное десятилетие (1906-1916) как национальный русский ренессанс, но, с другой стороны, отмечает, что этот ренессанс страдал неизлечимым пороком, имя которому - имморализм. Этот имморализм вполне объясним как реакция против предшествующего ему морального гиперболизма, но, в конце концов, именно он оказался роковым для «всех движений, родившихся в это великое и смутное время» $[10$, с. 6]. Отсюда православный модернизм и усвоил свой основной недостаток - подмену этики эстетикой.

Федотов делает анализ того, как происходила эта подмена. Этику и эстетику он считает сходными по приложению (обе, в отличие от познания, имеют дело «с миром должного», а не «с миром сущего»), но они различаются «ипостасными свойствами». Под влиянием идей пореволюционного десятилетия в моду входила «известная снобистская брезгливость по отношению к морали, как к низшей, вульгарной особе, которой нечего делать на вершинах духа в царстве религии и которая не может и равняться со своей небесной сестрой - красотой. Мораль считалась - и считается - делом нужным, социально полезным, но пресным, скучным и не имеющим ничего общего со спасением (теперь принято говорить с “обожением”). Чтобы оправдать такое презрительное отношение к морали, ее начали трактовать исключительно как законническую мораль, т. е. как требование общезначимых норм. Нетрудно убедиться, что закон не спасает, что благодать начинается там, где закон, как видел уже ап. Павел, показал свое бессилие» $[10$, с. 7]. «Перекодирование» нравственной жизни в эстетические категории, или, по выражению Федотова, «аннексия добра красотой», происходит следующим образом (здесь он использует аллюзию на известное изречение Микеланджело): «Если же есть в нравственной жизни (а это трудно отрицать) нечто высшее, что не укладывается в категории законнической морали, ну - тогда это высшее может быть истолковано в терминах эстетики: как душевная или духовная красота. С этой точки зрения нравственная жизнь человека может быть уподоблена работе художника над своим материалом. Из глыбы природного камня человек постепенно, в течение целой жизни, высекает идеальный образ, соответствующий замыслу Творца о нем - своему первообразу» [10, с. 7].

Одним из характерных признаков модернизма Федотов считает минимизацию нравственной составляющей Евангелия. «Не оставляет ли нравственное учение девять десятых этой книги?»- риторически спрашивает он, а затем довольно язвительно пишет: «Впрочем, говоря об Евангелии, чувствуешь, 
что совершаешь недопустимую бестактность, с тех пор, как Толстой принялся толковать Евангелие, ссылаться на него стало признаком дурного тона. Мы все знаем теперь, что в Евангелие важны события земной жизни Христа с их мистическим смыслом для жизни Церкви, а не заполняющие промежутки между ними притчи и “логии”, от Рождества - к Крещению, от Крещения к Преображению Евангелие заполняет круг церковного праздничного года. Останавливаться на Нагорной проповеди можно предоставить сектантам. Действительно, потускнение Евангелия есть одно из самых поразительных явлений нашего религиозного возрождения, и оно, несомненно, стоит в связи с развенчанием морали» $[10$, с. $7-8]$.

Здесь следует остановиться на вопросе о том, что Федотов считает «нравственным актом», то есть основной составляющей этики. Этический мир, с его точки зрения, подобен по своей организации миру эстетическому. Механическое применение законов эстетики в творчестве не способно создать полноценное художественное произведение. Оно создается «конкретной интуицией художника», который на основе законов эстетики строит «нечто неповторяющееся». Нравственный акт подобен созданию произведения. «Нравственный поступок состоит вовсе не в приложении закона. Последнее имеет место в низшей моральной сфере, соответствующей низшей сфере искусства - почти механической репродукции» $[10$, с. 10]. Нравственный акт - это не механическое следование закону или установленным нормам (тем более что они могут сильно различаться и противоречить друг другу), поэтому «не законы определяют нравственное значение акта, а усмотрение оптимальности, т. е. выбора наилучшей из возможностей» $[10$, с. 10]. Нравственный акт - это результат сложного взаимодействия внешних норм, условий и внутренних убеждений, он «лежит посередине между внутренним и чисто внешним и является настоящей связью между мирами, или исходом личности в мир» [10, c. 11].

В рамках христианской этики Федотов уподобляет нравственный акт пророчеству, разница только в масштабе и объеме действия. Но и то и другое имеет общую осно- ву - способность услышать и понять волю Божию здесь и сейчас («hic et nunc») и исполнить ее. Этой этической философии Федотов прямо противопоставляет православный модернизм. В согласии с общей системой ценностей модерна он подменяют этику эстетикой, но его частной особенностью является то, что в качестве нравственной философии или даже богословия он предлагает аскетику. А аскетика, с точки зрения Федотова, не нравственный, а эстетический феномен: «Аскетика есть искусство - создания совершенного человека. Выработанная античной философией техника работы над душевной природой была поставлена в христианстве на служение высшей религиозной задаче - “обожения". Но метод сохранил свой характер - искусства. Аскет в неустанном труде и вдохновении работает над неподатливым материалом, своей греховной природы, как скульптор над мрамором. Постепенно, в ежедневном, ежечасном усилии, отсекаются лишние куски, нащупываются истинные линии Богом созданной и человеком загубленной статуи (иконы, образа). Эта работа, поглощающая всего человека, требует затвора в своей духовной мастерской. Изоляция от внешнего мира является необходимым условием сосредоточения. При удаче достигаются изумительные результаты» [10, с. 15].

Однако применение аскетики как нравственного учения для поведения христиан в миру оказывается, с точки зрения Федотова, катастрофой: «При выходе из мастерской в мир эта система отказывается служить. Точнее, она является подспорьем... но она не дает ответа в жизненных конфликтах. В нравственных конфликтах от личности требуется высшая степень объективности: забыть о себе, даже о своем духовном благе, чтобы выполнить то веление правды, с которым Бог обращается к ней. Аскет не привык к такой “внешней” установке; она кажется ему слишком “мирской”. Святой (который уже выше аскетики), конечно, найдет выход во всяком жизненном конфликте. Но средний монах скорее запутается в них. Большинство из нас не монахи, а люди мира. Но привычка смотреть на конфликты мира глазами аскета убивает их нравственное значение. Существует тенденция уклониться от решения, уйти в тот внут- 
ренний мир, где все заранее решено. Внешние поступки признаются заранее малоценными. Там, где аскетика оставляет без помощи, там вступает в свои права жизненная рутина, т. е. рабствование законам мира» [10, с. 16].

Получается, что современный православный христианин в своей повседневной жизни руководствуется законами «мира сего», оказываясь неспособным ничего им противопоставить. «Дух компромисса - оцерковленный, он называется, как известно, “икономией” - надо всем господствует. За отсутствием привычной власти, мы ищем опоры в “общественном мнении”, в политических силах, если не в партиях, на каждом шагу предавая наше “свидетельство” ради национального, политического и бытового консерватизма» $[10$, c. 16-17]. Диагноз, поставленный Федотовым той «подлой экклезиологии», которой руководствуются его идейные противники, чрезвычайно пессимистичен по своим последствиям: «В этом ключ ко многим слабостям и неудачам нашего церковного возрождения. Здесь объяснение нашей немощи, какой-то бесхребетности, которая поражает при сравнении с активностью злых сил нашей эпохи. $<$...> Живя в обстановке безмерной свободы, мы отказываемся ею пользоваться. Вместо того, чтобы вести сильных, будить спящих, звать к покаянию и новой жизни, мы идем с ними, стараясь не отставать, - к общей яме» [10, с. 16-17].

Результаты. Как мы уже писали, конфликт Федотова с Правлением Богословского института был действительно конфликтом с Правлением, а не с отдельными его членами [5, c. 64]. Его анализ показывает, что кампания главного редактора «Возрождения» против института была купирована митрополитом Евлогием довольно быстро (к 17 февраля 1939 г.), конфликт Федотова с митрополитом (при посредничестве м. Марии) к 21 февраля также был улажен (см.: [4, с. 60-61]). Все, что происходило потом (резолюция Правления от 30 марта 1939 г. и дальнейшее затягивание конфликта), можно объяснить только одним - интригами «группы» и следованием остальной части Правления в ее фарватере. Изначально «сторона Федотова» не делает ставку на то, чтобы путем огласки конфликта в иностранной прессе оказать давление на международ- ные экуменические круги, финансирующие институт, но в качестве возможного варианта рассматривает и ее. Она пытается в качестве фактора давления организовать широкую кампанию в эмигрантской прессе в защиту Федотова. После провала этого замысла (главным образом из-за позиции «Последних новостей»), повторной резолюции Правления и появления статьи Бердяева организация кампании в защиту Федотова в западной прессе и широкая огласка причин конфликта в тех экуменических кругах, которые финансировали институт, постепенно становятся основной тактической линией. Не последнюю роль в нейтрализации «группы», вероятно, сыграл и повторный ответ Федотова Правлению: он был сделан на запрос митрополита Евлогия (через посредничество м. Марии) именно для этой цели.

Понимая (после провала кампании против Бердяева), что в случае широкой огласки сути конфликта в западной прессе институт может лишиться финансирования, а профессора потерять «экзистенц-минимум», Правление предпочло его замять, не увольняя Федотова, но и не сняв с него порицания. Как свидетельствует переписка, это решение было принято не позднее чем в начале-середине июня. Поэтому кочующее из статьи в статью и ставшее уже неким «топосом» мнение, что начавшаяся война разрешила все споры (Федотова с Правлением) $[4$, с. $474 ; 8$, с. 24] (ср.: [6, с. 131), не соответствует действительности.

Начало войны не имело ровно никакого влияния на разрешение конфликта. Переписка ясно показывает, что Федотов тяготился дальнейшим общением со своими коллегами по институту (чем и был обусловлен его уход из Правления) и остался преподавать в институте только из-за студентов. Поэтому подвергать сомнению часто цитируемую его фразу, приводимую женой («Одно, слава Богу, с Богословским институтом все кончено» [11, c. XXVII]), нет никаких оснований. Ясно, что сложившиеся обстоятельства (быстрое продвижение гитлеровских войск к Парижу в мае - июне 1940 г.) просто ускорили для него решение об уходе из института и эмиграции в США. В этой связи нас очень удивляет позиция А.В. Антощенко, склонного обвинять во всем жену Федотова, которая якобы «приписала» ему непримиримую позицию по отно- 
шению к коллегам [1, с. 213]. Федотов достаточно ясно указывал свое отношение к ним в письме к Бердяеву, которое хорошо известно: «Но, признаюсь откровенно, в глубине души я был бы рад, если бы Ваша статья переполнила чашу, и меня уволили бы из Института. Право, об этом мечтаю. Невыносимо думать, что осенью буду сидеть за столом с этими бесчестными людьми (курсив наш. $A$. B. )» [3, c. 365]. Поэтому, на наш взгляд, пока нет никаких оснований подвергать сомнению замечание Е.Н. Федотовой, что в Париже, по приезде из Англии, ее мужу пришлось бы «во3вращаться в уже давно ставшую ему тяжелой обстановку Богословского института» [11, c. XXIX] (cp.: [1, с. 212]). А о том, что на решение Федотова эмигрировать в США повлияла позиция его жены, не скрывая пишет она сама $[11$, с. XXVIII].

События, связанные с конфликтом, явились причиной рефлексии Федотова об идейных различиях между ним и членами Правления (или шире - профессуры Богословского института) во взглядах на христианство. Причины поведения своих коллег Федотов склонен видеть в идеологии «церковного возрождения» (то есть православного модернизма), основной особенностью которого, с его точки зрения, является подмена этики эстетикой, что, помимо прочего, выражается во взгляде на аскетику как на нравственное богословие. Применение принципов аскетики для поведения христианина в миру неизбежно терпит крах и приводит либо к пассивности, либо к действиям по законам «мира сего» (что, отметим, полностью совпадает с парадигмой поведения членов Правления во время конфликта). Отказавшись от выработки самостоятельного нравственного богословия для жизни в миру, христиане оказываются не способными отвечать на вызовы времени. Нет сомнений в том, что свой идеал христианской жизни Федотов связывал с социальным служением, с той «каритативной» составляющей христианства, которую он так ценил в древнерусской святости и которой старались следовать его соратники по «Православному делу».

\section{ПРИМЕЧАНИЕ}

${ }^{1} \mathrm{C}$ исправлением по архивному оригиналу (Columbia University Libraries. BakhmeteffArchive.
Ms. coll Fedotov. Box 8. Письмо к жене от 13 марта 1939 г., машинопись). В публикации ошибочно стоит «беззаконности».

Мы благодарим И.В. Голубович за любезно присланную фотокопию архивного оригинала.

\section{СПИСОК ЛИТЕРАТУРЫ}

1. Антощенко, А. В. Конфликт между Г.П. Федотовым и Правлением Свято-Сергиевского Православного института в Париже / А. В. Антощенко // Вестник РХГА. - 2014. - Т. 15, вып. 1. - С. 210-214.

2. Бердяев, Н. А. Существует ли в православии свобода мысли и совести? / Н. А. Бердяев // Путь. 1939. - № 59. - C. 46-54.

3. Бычков, С. С. Конфликт в Свято-Сергиевском Богословском институте (1939 г) / С. С. Бычков // Собрание сочинений : в 12 т. / Г. П. Федотов. M. : Sam \& Sam, 2008. - T. 12. - C. 262-378.

4. Бычков, С. С. Послесловие / С. С. Бычков // Собрание сочинений : в 12 т / Г. П. Федотов. - М. : Sam \& Sam, 2008. - T. 12. - C. 464-482.

5. Войтенко, А. А. «Напишу, что я отныне не уважаю своих коллег». Действующие лица конфликта Г.П. Федотова с Правлением Богословского институга в Париже (1939) / А. А. Войтенко // Вестник Волгоградского государственного университета. Серия 4, История. Регионоведение. Международные отношения. - 2017. - Т. 22, № 4. - С. 56-65.DOI: https://doi.org/10.15688/jvolsu4.2017.4.6.

6. Галямичева, А. А. Свобода слова в русской эмиграции: конфликт профессора Г. П. Федотова с правлением православного Богословского института в Париже / А. А. Галямичева // Вестник Саратовского государственного социально-экономического университета. - 2008. - № 5 (24). - С. 131-133.

7. К 110-летию Георгия Федотова. Документы и письма по поводу разногласия, возникшего между профессором Г. П. Федотовым и Правлением Богословского института в Париже / подгот. Д. Бон // Звезда. - 1996. - № 10. - С. 117-151.

8. Мень, А., прот. Возвращение к истокам / А. Мень, прот. // Святые Древней Руси / Г. Федотов. - М. : Моск. рабочий, 1990. - С. 7-26.

9. Семенов, Ю. Ф. Огорчение Керенского / Ю. Ф. Семенов // Возрождение. - 1939. - 24 февр. (№ 4172). - C. 3 .

10. Федотов, Г. П. В защиту этики / Г. П. Федотов // Путь. - 1939. - № 60. - С. 4-17.

11. Федотова, Е. Н. Георгий Петрович Федотов (1886-1951) / Е. Н. Федотова // Лицо России : Статьи, 1918-1930 / Г. П. Федотов. - Париж : Ymca-Press, 1988.-C. I-XXXIV.

12. Яновский, В. С. Поля Елисейские. Книга памяти / В. С. Яновский-СПб. : Пушкинский фонд, 1997. -277 c. 


\section{REFERENCES}

1. Antoshchenko A.V. Konflikt mezhdu G.P. Fedotovym i Pravleniem Svyato-Sergievskogo Pravoslavnogo instituta v Parizhe [The Conflict between Georgy Fedotov and the Board of St. Sergius Orthodox Institute in Paris]. Vestnik RKhGA, 2014, vol. 15 , iss. 1, pp. 210-214.

2. Berdyaev N.A. Sushchestvuet li v pravoslavii svoboda mysli i sovesti? [Does Freedom of Thought and Conscience Really Exist in Orthodoxy?]. Put, 1939. no. 59 , pp. 46-54.

3. Bychkov S.S. Konflikt v Svyato-Sergievskom Bogoslovskom institute (1939 g.) [The Conflict in the St. Sergius Theological Institute (1939)]. Fedotov G.P. Sobranie sochineniy: $v 12 \mathrm{t}$. [Collected Works in 12 Volumes]. Moscow, Sam \& Sam, 2008, vol. 12, pp. 262-378.

4. Bychkov S.S. Posleslovie [Afterword]. Fedotov G.P. Sobranie sochineniy: $v 12 t$. [Collected Works in 12 Volumes]. Moscow, Sam \& Sam, 2008, vol. 12, pp. 464-482.

5. Voytenko A.A. «Napishu, chto ya otnyne ne uvazhayu svoikh kolleg». Deystvuyushchie litsa konflikta G.P. Fedotova s pravleniem bogoslovskogo instituta v Parizhe (1939) ["I Will Write That I no Longer Respect My Colleagues". Parties in G.P. Fedotov's Conflict with the Board of St. Sergius Orthodox Institute in Paris (1939)]. Vestnik Volgogradskogo gosudarstvennogo universiteta. Seriya 4, Istoriya. Regionovedenie. Mezhdunarodnye otnosheniya [Science Journal of Volgograd State University. History. Area Studies. International Relations], 2017, vol. 22, no. 4, pp. 56-65. DOI: https://doi.org/10.15688/ jvolsu4.2017.4.6.
6. Galyamicheva A.A. Svoboda slova v russkoy emigratsii: konflikt professora G.P. Fedotova s pravleniem Pravoslavnogo bogoslovskogo instituta v Parizhe [Freedom of Speech in the Russian Emigration: Conflict of Professor Georgy Fedotov with the Board of the Orthodox Theological Institute in Paris]. Vestnik Saratovskogo gosudarstvennogo sotsialno-ekonomicheskogo universiteta [Vestnik of Saratov State Socio-Economic University], 2008, no. 5 (24), pp. 131-133.

7. Bon D., ed. K 110-letiyu Georgiya Fedotova. Dokumenty i pisma po povodu raznoglasiya, voznikshego mezhdu professorom G. P. Fedotovym i Pravleniem Bogoslovskogo instituta v Parizhe [To the $110^{\text {th }}$ Anniversary of Georgy Fedotov. Documents and Letters about the Disagreement that Arose between Professor Georgy Fedotov and the Board of the Theological Institute in Paris]. Zvezda, 1996, no. 10, pp. 117-151.

8. Men A., prot., Vozvrashcheniek istokam [Back to the Roots]. Fedotov G. Svyatye Drevney Rusi [Saints of Ancient Rus]. Moscow, Moskovskiy rabochiy Publ., 1990, pp. 7-26.

9. Semenov Yu.F. Ogorchenie Kerenskogo [Chagrin of Kerensky]. Vozrozhdenie, 1939, 24 February(no. 4172), p. 3.

10. Fedotov G.P. V zashchitu etiki [To Defence of Ethics]. Put, 1939, no. 60, pp. 4-17.

11. Fedotova E.N. Georgiy Petrovich Fedotov (18861951) [Georgy Fedotov (1886-1951)]. Fedotov G.P. Litso Rossii: Statyi, 1918-1930 [The Face of Russia. Articles, 1918-1930]. Paris, Ymca-Press, 1988, pp. I-XXXIV.

12. Yanovskiy V.S. Polya eliseyskie. Kniga pamyati [The Champs Elysees. A Memory Book]. Saint Petersburg, Pushkinskiy fond Publ., 1997. 277 p.

\section{Information about the Author}

Anton A. Voytenko, Candidate of Sciences (History), Leading Researcher, Centre for Egyptological Studies, Russian Academy of Sciences, Prosp. Leninskiy, 29, bld. 8, 119071 Moscow, Russian Federation, cesras@cesras.ru, https://orcid.org/0000-0002-3895-9909

\section{Информация об авторе}

Антон Анатольевич Войтенко, кандидат исторических наук, ведущий научный сотрудник, Центр египтологических исследований РАН, Ленинский просп., 29, стр. 8, 119071 г. Москва, Российская Федерация, cesras@cesras.ru, https://orcid.org/0000-0002-3895-9909 